\title{
Pérola and Smooth Cayenne pineapple cultivars in the state of Bahia, Brazil: growth, flowering, pests, diseases, yield and fruit quality aspects
}

Domingo Haroldo Reinhardt*, José Renato Santos Cabral, Luiz Francisco da Silva Souza, Nilton Fritzons Sanches, Aristóteles Pires de Matos

Embrapa Mandioca

e Fruticultura,

Caixa Postal 007,

44380-000 Cruz das Almas,

Bahia, Brazil

dharoldo@cnpmf.embrapa.br

${ }^{*}$ Correspondence and reprints

Received 28 December 2000 Accepted 23 July 2001

Fruits, 2002, vol. 57, p. 43-53 (c) 2002 Cirad/EDP Sciences All rights reserved DOI: 10.1051/fruits:2002005

Resumen EsPañol, p. 53

\section{Pérola and Smooth Cayenne pineapple cultivars in the state of Bahia, Brazil: growth, flowering, pests, diseases, yield and fruit quality aspects.}

Abstract - Introduction. Pérola, the most important cultivar in Brazil and almost unknown in other countries, and Smooth Cayenne, the most grown cultivar in the world, belong to different pineapple groups with distinct botanical, morphological and agronomic characteristics. The principal characteristics and behavior of the $\mathrm{cv}$. Pérola pineapple were analyzed, in comparison with the $\mathrm{cv}$. Smooth Cayenne ones. Materials and methods. A comparison between Pérola and Smooth Cayenne was done, based upon results and observations made in studies carried out by Embrapa in Brazil, during the past 20 years. Results and discussion. The cv. Pérola plant usually has a smaller stem than the cv. Smooth Cayenne with a lower number of roots and leaves, but the ' $\mathrm{D}$ ' leaves are longer, wider and more erect. The peduncle is longer, holding a narrower, longer, cone-shaped fruit, with a whitish, less fibrous flesh and edible central core, lower acidity and higher [(total soluble solids) / (titrable acidity)] ratio and juice content. The cv. Pérola is more sensitive than the cv. Smooth Cayenne to natural and artificial flowering induction, but it is less susceptible to the wilt disease transmitted by mealy bugs and to the stem borer (Castnia icarus). Cv. Pérola produces many slips, but suckers appear later, are less uniform and less well-fixed to the mother plants, making it more difficult to get a good first ratoon crop. Conclusions. The yield potential of the cv. Pérola is lower than that of the $\mathrm{cv}$. Smooth Cayenne, due to a lighter fruit and usually lower planting density used. Its production costs are also lower, especially due to cheaper planting materials and a lower number of pesticide applications. The overall performance of the $\mathrm{cv}$. Pérola plants and fruits explains the wide use of this variety in Brazil and its potential use in other countries.

Brazil / Ananas comosus / variety trials

\section{Les cultivars 'pérola' et 'cayenne lisse' dans l'État de Bahia au Brésil :} croissance, floraison, parasites, maladies, rendement et qualité du fruit.

Résumé - Introduction. Les cultivars 'pérola', le plus important au Brésil et presque inconnu dans d'autres pays, et 'cayenne lisse', le plus développé dans le monde, appartiennent à deux groupes d'Ananas comosus différents, présentant des caractéristiques botaniques, morphologiques et agronomiques distinctes. Ces caractéristiques et le comportement de ces cultivars dans un environnement donné au Brésil ont été analysés. Matériel et méthodes. Une comparaison entre les cultivars pérola et cayenne lisse a été faite en s'appuyant sur des résultats et des observations faites lors d'études effectuées par l'Embrapa au Brésil, durant les 20 dernières années. Résultats et discussion. Les plants du cv. pérola présentent habituellement une tige plus petite que ceux du cv. cayenne lisse ainsi qu'un nombre inférieur de racines et de feuilles, mais les feuilles 'D' sont plus longues, plus larges et plus érigées. Le pédoncule est plus long, soutenant un fruit conique, plus étroit, plus long, avec une pulpe moins fibreuse, blanchâtre et un coeur comestible. Son acidité est inférieure et son rapport [extraits secs solubles / acidité titrable] est plus élevé que ceux de cayenne lisse, de même que sa teneur en jus. Pérola est plus sensible que cayenne lisse à l'induction florale naturelle ou artificielle, mais il est moins sensible à la maladie du wilt transmise par la cochenille farineuse et au ravageur de la tige (Castnia icarus). Pérola produit beaucoup plus de rejets du type bulbille, mais ses cayeux apparaissent plus tard, sont moins homogènes et moins bien fixés aux plants, ce qui ne permet pas de bons rendements en deuxième récolte. Conclusions. Le rendement potentiel du cv. pérola est inférieur à celui du cv. cayenne lisse du fait de son fruit moins lourd et de sa densité de plantation habituellement plus faible. Ses coûts de production sont également inférieurs à cause, surtout, d'un matériel végétal de replantation moins cher et du nombre inférieur d'applications de pesticides. La performance générale des plants et des fruits de pérola explique sa large utilisation au Brésil et sa possible exploitation dans d'autres pays.

Brésil / Ananas comosus / essai de variété 


\section{Introduction}

Pineapple production and industrialization in the world is dominated by just one cultivar, the 'Smooth Cayenne'. In most international trades and in the most important markets of pineapple-importing countries, especially in Europe and the United States, almost all fresh fruits and canned products come from this cultivar. The Smooth Cayenne plant and fruit have many excellent characteristics that have made it the 'queen' of the pineapple varieties among growers and international traders.

There are, however, many other varieties of pineapple grown into many different countries that have very good growing and fruit qualities [1]. The main pineapple cultivars were classified into five different groups, based upon a set of common characteristics within each group, especially those related to the plant size, number of slips, presence of spines along the leaf margins, leaf length, peduncle length, leaf color, fruit weight and shape, fruit rind and pulp colors, fruitlet form and fruit taste [2]. Based upon these attributes, the Smooth Cayenne belongs to the Cayenne group and the 'Pérola' to the Pernambuco group. Among the morphological characteristics, the presence of spines along the leaf margins of the 'Pérola' plants is one of the most evident differences in relation to the Smooth Cayenne plants which have only few, short spines at the leaves' apices.

The pineapple industry in Brazil uses both cultivars, Pérola and Smooth Cayenne. An estimated $80 \%$ of the 55000 ha of pineapple harvested in Brazil in 1997 was cultivated with the Pérola variety [3]. In the Brazilian North and Northeast regions, it may be used for almost $100 \%$ of the planted and harvested commercial areas. On the other hand, the Smooth Cayenne variety is mostly grown and consumed in the Southeast and South regions of the country.

Its many good and favorable attributes and properties, not only for cultivation, but also for fulfilling the requirements of fresh fruit consumers in most of the domestic markets, make the Pérola fruit the dominant one on the large Brazilian market. Nevertheless, it is almost unknown in overseas markets. In addition, the scientific and academic world involved with pineapple research and development has had little information about this cultivar due to its exploitation being restricted to Brazil and some neighboring countries.

The present work had the main objective of showing the principal characteristics and behavior of the Pérola pineapple cultivar, in comparison with the world pattern of pineapple, the Smooth Cayenne cultivar.

\section{Materials and methods}

The comparison between the two pineapple cultivars, Pérola and Smooth Cayenne, was based on data obtained in different studies carried out by Embrapa Mandioca e Fruticultura in Brazil, during the past twenty years. Those have been studies with the specific objective of evaluating pineapple germplasm, using Pérola and Smooth Cayenne as control treatments, or with other goals, such as to determine the influence of planting dates, planting materials and other factors, as well as cultural practices, on the vegetative and reproductive behavior of the plants of those cultivars during their cycle. In addition, observations made by the authors in commercial plantings in different pineapple-producing regions (Entre Rios, Bahia; Coração de Maria, Bahia; Sapé, Paraíba; Mocambinho, Monte Alegre de Minas and Canápolis, Minas Gerais) in Brazil have been taken into account for this comparison.

Most of the data used have been obtained in experiments carried out in experimental fields of Embrapa Mandioca e Fruticultura, located in Cruz das Almas, Bahia, in the Recôncavo Baiano region, at lat. $12^{\circ} 40^{\prime}$ $19^{\prime \prime} \mathrm{S}$ and long. 39 06' $22^{\prime \prime} \mathrm{W}, 220 \mathrm{~m}$ above sea level, with an average annual rainfall of $1170 \mathrm{~mm}$ and average temperature of $24.5^{\circ} \mathrm{C}$. The soils are yellow or yellow-red latosoils, of mostly intermediate to high acidity ( $\mathrm{pH}$ in water equal to 4.5 to 5.5 ), low chemical fertility (phosphorus $<10 \mathrm{mg}$ $\times \mathrm{dm}^{-3}$; potassium: (30 to 90) $\mathrm{mg} \times \mathrm{dm}^{-3}$; calcium $<2.0 \mathrm{cmol} \times \mathrm{dm}^{-3}$; magnesium 
$<1.2 \mathrm{cmol} \times \mathrm{dm}^{-3}$; bases saturation from $40 \%$ to $60 \%$; with (0.0 to 0.5$) \mathrm{cmol} \times \mathrm{dm}^{-3}$ of aluminum), usually deep, well drained, with an intermediate texture.

These environmental conditions are characteristic of the coastal tablelands that form a long strip from Rio Grande do Norte state (in the North of the Brazilian Northeast region) to Rio de Janeiro (in the Southeast region), and have been the site for a major part of the traditional pineapplegrowing areas, as well as for most of the research activities on this crop carried out in Brazil.

All experiments were done without irrigation, but using mineral fertilizations, integrated pest, disease and weed controls, and flowering forcing treatments mostly at (10 to 12) months after planting, with fruit harvests occurring ( 5 to 6 ) months later. The planting was mainly done at the beginning of the rainy season (March/April), using slips for the Pérola cultivar and mostly suckers for the Smooth Cayenne cultivar. The most used planting spacements and densities were $0.80 \mathrm{~m} \times 0.30 \mathrm{~m}$ (41600 plants $\times$ $\mathrm{ha}^{-1}$ ) in a simple-row planting system and $0.90 \mathrm{~m} \times 0.40 \mathrm{~m} \times 0.40 \mathrm{~m}$ (37030 plants $\times \mathrm{ha}^{-1}$ ) for the Pérola cultivar and $0.90 \mathrm{~m} \times$ $0.40 \mathrm{~m} \times 0.30 \mathrm{~m}\left(51200\right.$ plants $\left.\times \mathrm{ha}^{-1}\right)$ for the Smooth Cayenne cultivar, both in double-row systems. The cultural practices used largely followed the technical recommendations for the Brazilian pineapple crop described in a recent publication [4].

Several experimental designs and numbers of treatments and replications were used in the studies from which the information for this work has been extracted. Among those, the randomized blocks one, with or without split-plots, was the most used [5, 6]. Experimental plot size also varied, but, in general, was of at least 50 plants. All plot plants were evaluated for the production variables, whereas the vegetative and fruit internal quality variables were based upon samples of $5 \%$ to $10 \%$ of the plants or fruits. The variables used for treatment evaluation were the following:

- vegetative stage of the plants: plant height and ' $\mathrm{D}$ ' leaf length, intermediate width and weight, as well as number of leaves emitted from planting to flowering forcing treatment;

- reproductive stage: yield, fruit weight, dimensions and chemical or physical-chemical characteristics, such as total soluble solids, titrable acidity, [(total soluble solids)/ (titrable acidity)] ratio, juice percentage;

- number of shoots per plant (slips and suckers), percentage of fruits with fasciation, and incidence of pests and diseases.

Even though statistical analyses, mostly analyses of variance and means comparison tests, have been used in most of the individual experiments, in this synthesis work data are presented without statistical analyses.

\section{Results and discussion}

\subsection{Morphological and vegetative aspects}

Looking at each organ separately, many differences [1, 7-12] were observed between the two cultivars (table I). The Pérola leaves are longer, wider and heavier (figure 1) than that of the Smooth Cayenne. However, the latter forms a larger number of leaves, showing a denser canopy. In addition, its leaves are less erect, and the plant is overall smaller, an advantage for the application of cultural practices and for harvest. On average, the Smooth Cayenne plants emit about one leaf per week until the flowering forcing treatment, whereas the Pérola plants take, on average, two or three days longer for that. The overall fresh and dry weights of the leaves are similar for both cultivars, although with slightly higher values for the Pérola.

On the other hand, the Smooth Cayenne plant has a more developed root system and stem. Both organs have higher weights for this cultivar. And it also emits a higher number of roots, that are slightly longer on average. Another interesting property of the Smooth Cayenne stems are their high starch content, which would make them a more useful source for ethylic alcohol production. 


\section{Table I.}

Comparison of two cultivars of pineapple (Ananas comosus), Pérola versus Smooth Cayenne, according to results obtained in Cruz das Almas, Bahia, Brazil, by the Embrapa Mandioca e Fruticultura (Embrapa Cassava and Fruit Crops).

\begin{tabular}{|c|c|c|}
\hline Topics & Pérola & Smooth Cayenne \\
\hline \multicolumn{3}{|l|}{ Roots $^{1}$} \\
\hline Number (first-order roots) & 40 & 53 \\
\hline Length $(\mathrm{cm})$ (average) & 13 & 17 \\
\hline Dry weight (g) & 18 & 26 \\
\hline \multicolumn{3}{|l|}{ Stem } \\
\hline Fresh weight (g) & $300^{1}$ & $370^{1}$ \\
\hline Dry weight (g) & $100^{1}$ & $120^{1}$ \\
\hline Starch content (\% dry weight) & $24.3^{4}$ & $57.1^{4}$ \\
\hline \multicolumn{3}{|l|}{ Leaves $^{1}$} \\
\hline Number (leaves emitted) & 30 & 46 \\
\hline Length ('D’ leaf) (cm) & 84 & 67 \\
\hline Width ('D' leaf) (cm) & 6.8 & 5.2 \\
\hline Fresh weight (g) & 1550 & 1350 \\
\hline Dry weight (g) & 270 & 255 \\
\hline \multicolumn{3}{|l|}{ Peduncle } \\
\hline Length $(\mathrm{cm})$ & $34.0^{2}$ & $20.3^{2}$ \\
\hline Diameter $(\mathrm{cm})$ & $2.8^{2}$ & $2.6^{2}$ \\
\hline Weight (g) & $14^{1}$ & $10^{1}$ \\
\hline Slip number & $10.0^{2}$ & $1.0^{2}$ \\
\hline Sucker number (at fruit harvest) & $0.0^{2}$ & $1.0^{2}$ \\
\hline \multicolumn{3}{|l|}{ Crowns } \\
\hline Length (cm) & $16.9^{2}$ & $23.2^{2}$ \\
\hline Weight (g) & $100^{2}$ & $276^{2}$ \\
\hline Fasciation (\%) & $2.3^{1}(3.3)^{3}$ & $24.0^{1}(9.9)^{3}$ \\
\hline \multicolumn{3}{|l|}{ Fruit $^{1}$} \\
\hline Length (cm) & 20.5 & 16.6 \\
\hline Total mid-diameter $(\mathrm{cm})$ & 10.6 & 13.6 \\
\hline Core diameter $(\mathrm{cm})$ & 2.3 & 3.1 \\
\hline Fresh weight (g) & $1.4-1.8$ & $1.8-2.2$ \\
\hline Total soluble solids (TSS) & 14.8 & 13.5 \\
\hline Total titrable acidity (TTA) & 6.4 & 10.2 \\
\hline TSS/TTA & 2.3 & 1.3 \\
\hline Juice (\%) & 81.9 & 78.7 \\
\hline \multicolumn{3}{|l|}{ Yield } \\
\hline First cycle (fruits $\times \mathrm{ha}^{-1}$ ) & $24000-33300^{1}$ & $26000-35500^{6}$ \\
\hline First Cycle $\left(\mathrm{t} \times \mathrm{ha}^{-1}\right)$ & $38-50^{1}$ & $45-60^{6}$ \\
\hline Ratoon crop $\left(\mathrm{t} \times \mathrm{ha}^{-1}\right)$ & $20-25^{5}$ & $30-40^{6}$ \\
\hline Production costs without irrigation (US\$) & $2200-3200^{7}$ & $2800-4000^{7}$ \\
\hline
\end{tabular}


The peduncle is longer and heavier in the Pérola pineapple, but its diameter is about the same of that of the Smooth Cayenne. A shorter and more resistant peduncle is important for avoiding the dropping of fruits at their maturation period, which usually makes them more susceptible to sunburns. However, the Pérola pineapple fruit is usually more protected from sunburns than that of the Smooth Cayenne due to the presence of many slips, most of them on the upper part of the peduncle growing around the fruit (figure 2). The number of slips varies according to environmental conditions, particularly during the floral differentiation period, and to the cultural practices carried out on the crop. However, there are five to fifteen slips per Pérola plant [13], whereas the Smooth Cayenne plant has just a few slips or no slips at all, when the floral differentiation occurs in a hot and dry season. On the other hand, this variety has a higher capacity of sucker production, this type of shoot being the main planting material for that cultivar in Brazil, whereas slips are the most common planting material used for Pérola pineapple crops. Smooth Cayenne fruit crowns are mostly more vigorous, being heavier and sometimes longer than those from Pérola plants, and therefore they have been used as planting material in other countries, especially when fruits are used for the canning industry. The Smooth Cayenne pineapple plants are much more susceptible to environmental conditions that determine the appearance of morphological anomalies. One of the most important anomalies is the fasciation that affects Smooth Cayenne crowns or even the fruit and the peduncle to a much larger extent than in Pérola plants. This anomaly may represent significant Smooth Cayenne fruit losses under certain circumstances, but is not a problem in Pérola plantations.

\subsection{Flowering, pests and diseases}

Pérola shows much more sensitivity to floral differentiation than Smooth Cayenne (table II). This is true for flowering (figure 3) determined by natural conditions, as well as by artificial forcing treatments [14]. Early in the season with environmental con-

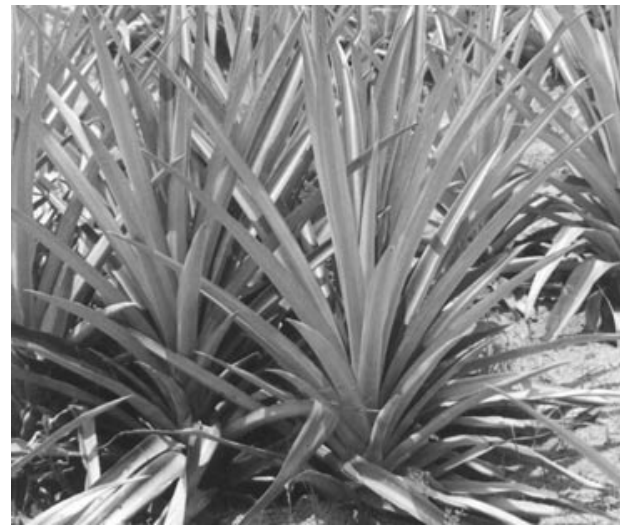

Figure 1.

A cv. Pérola pineapple plant, about 7 months old. Note the erect leaves and the low leaf density.

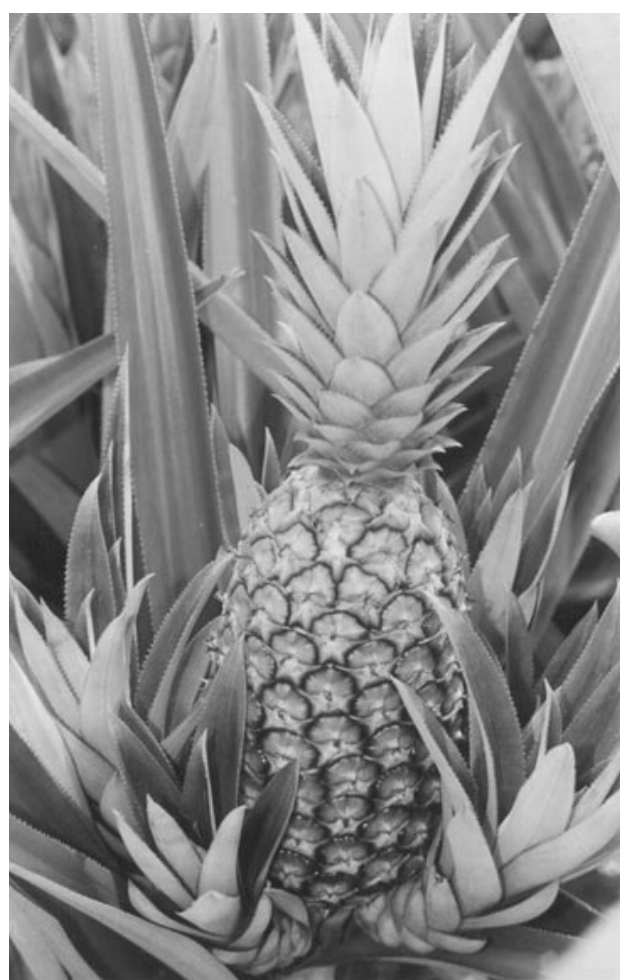

Figure 2.

A cv. Pérola pineapple plant with its large fruit, surrounded by several slips inserted on the upper part of the peduncle.

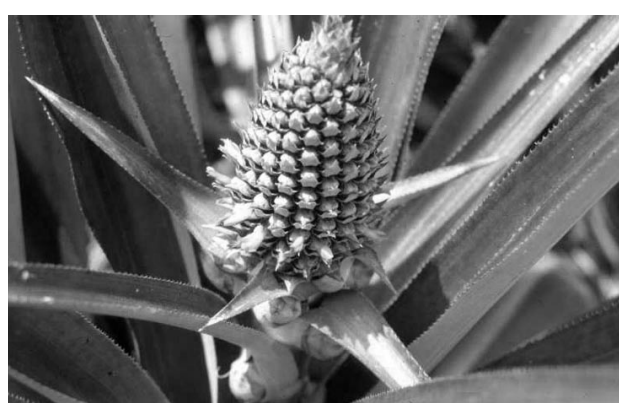

Figure 3.

A cv. Pérola pineapple plant at early flowering stage. Note the spines on the leaves' margins and the many slip buds. 
ditions that trigger the switching of pineapple plants from vegetation to reproduction, such as shorter days with lower insolation and cooler nights, Pérola plants can be observed starting to differentiate, whereas Smooth Cayenne plants of the same age and in a similar developmental stage usually need a longer period of inducing conditions to do the same. Similarly, forcing treatments fail more often for Smooth Cayenne plants than for Pérola plants. The concentrations of ethephon or calcium carbide required for getting good forcing efficiency is sometimes higher for Smooth Cayenne plants. As the same difference was often observed for treatments with other growth regulators, as, for example, with the 2-(3-chlorophenoxi) propionic acid which was sometimes used to delay the fruit harvest $[15,16]$, it can be concluded that the Pérola pineapple is, in general, more sensitive to the exogenous supply of growth regulators.

With respect to diseases, the major difference observed between the cultivars studied was the low incidence of wilt symptoms in Pérola plantations, confirming that this variety is tolerant to wilt [1, 13, 17]. Mealy bugs are usually present, but dispersed in areas within plantations showing plants with the typical wilting symptoms are rather seldom, whereas, in Smooth Cayenne plantations the wilt disease is as significant as the Fusarium disease, to which the Pérola plants are as susceptible as the Smooth Cayenne plants [18, 19]. So, integrated Fusarium control measures are vital for getting good returns in pineapple plantations of both cultivars [20, 21]. In addition, mealy bugs must be preventively attacked by chemicals to assure wilt disease control in Smooth Cayenne plantations [22]. Phytophthora disease is of low relevance for pineapple plantations in Brazil, except for some irrigated areas in the semi-arid region with almost neutral soil reactions [21]. No significant difference between the two cultivars could be observed, being both susceptible to that disease. The same is the case for the black rot caused by Thielaviopsis (Chalara) paradoxa, which is a disease that may cause significant planting material and fruit losses during the post-harvest period, but may be efficiently controlled by cultural and chemical measures.

Besides the mealy bugs associated with the wilt disease, the fruit borer (Thecla basalides) and the stem borer (Castnia icarus) are the other major pests present in Brazilian pineapple plantations (table II). Both varieties are attacked by these insects, but a recent study showed that there is a higher preference of the stem borer for Smooth Cayenne plants than for Pérola plants [23]. Nematodes, specially Pratylenchus brachyurus and Meloidogyne spp., are present in plantations of both varieties [24]. A study carried out at the Instituto Agronômico de Campinas, São Paulo, Brazil [25] indicated a higher susceptibility of Pérola to $P$. brachyurus than Smooth Cayenne which is strongly affected by this pest in most world production areas [3]. In Brazil, nematodes are considered a less important pest, even though losses due to their incidence have not yet been evaluated in a systematic way, and hence usually no nematode control is done in pineapple plantations, in contrast with the procedures in many other countries, particularly those that cultivate mainly the Smooth Cayenne.

\subsection{Yield, production cost, markets}

Other important differences between the two cultivars studied are related to fruit characteristics, yields and economical aspects. Pérola fruits are usually of a conic shape (figure 2), in contrast to the predominantly cylindrical shape of Smooth Cayenne fruits (figure 4) [8, 13]. Pérola fruits are commonly longer and narrower (smaller diameter) [7] (table I). The core diameter is also smaller, which contributes to the lower fiber content and higher juice content of these fruits [7]. In addition, these fruits are often of sweeter taste due to a higher [(total soluble solids)/(titrable acidity)] ratio, as a result of a lower acidity and, sometimes, a higher total soluble solids content [7, 13, 14]. These attributes make the Pérola fruit an excellent one for fresh fruit markets, particularly for those people who do not like acid fruits. However, its whitish pulp color, as well as its often less colored fruit rind are less attractive properties for consumers [13]. 


\section{Table II. \\ Principal advantages and disadvantages of Pérola and Smooth Cayenne pineapples (Ananas comosus).}

\begin{tabular}{|c|c|c|}
\hline Topics & Pérola & Smooth Cayenne \\
\hline Spines $^{1}$ & Yes & Few \\
\hline \multicolumn{3}{|l|}{ Flowering ${ }^{2}$} \\
\hline Natural & More sensitive, more precocious & Less sensitive \\
\hline Forced & Easier, more efficient & Harder, less efficient \\
\hline Growth regulators 3 & More sensitive & Less sensitive \\
\hline \multicolumn{3}{|l|}{ Diseases } \\
\hline Fusariosis $^{4}$ & Susceptible & Susceptible \\
\hline Black rot ${ }^{4}$ & Susceptible & Susceptible \\
\hline Wilt $^{5}$ & Tolerant & Susceptible \\
\hline Phytophthora 4 & Susceptible & Susceptible \\
\hline \multicolumn{3}{|l|}{ Pests } \\
\hline Fruit borer 6 & Susceptible & Susceptible \\
\hline Stem borer ${ }^{7}$ & Lower preference & Higher preference \\
\hline Nematodes $^{8}$ & Susceptible & Susceptible \\
\hline \multicolumn{3}{|l|}{ Fruit ${ }^{1}$} \\
\hline Shape & Conic & Cylindrical \\
\hline Pulp color & Whitish & Yellowish \\
\hline Rind color (ripe fruit) & More green than yellow & More yellow than green \\
\hline \multicolumn{3}{|l|}{ Markets $^{9}$} \\
\hline Domestic - fresh fruit & Excellent & Less accepted \\
\hline Domestic - industry & Good & Excellent \\
\hline Foreign & Weak & Excellent \\
\hline
\end{tabular}

Finally, the Smooth Cayenne variety has a clear advantage in the average fruit weight, which is usually higher than that of the Pérola (table I). A difference of (300 to 400) g per fruit was common for plants of the same age and grown under similar environmental conditions $[7,14]$. If there are less favorable growth conditions, the fruit weight may be the same for both cultivars, even though no data are available to compare the behavior of the two cultivars under environmental stress (drought, salinity, aluminum, and others) conditions.

A consequence of the lower average fruit weight and of the usually lower planting density used for Pérola plantations is the smaller yields in both the first and the ratoon cycles, obtained in well-managed plantations [11, 12] (table I). In addition, suckers of Smooth Cayenne plants are more strongly anchored to the mother plants than those of Pérola plants, which results in lower losses due to a lower percentage of plant and fruit dropping during the ratoon crop cycle. This problem, together with the increase of disease and pest incidence and the lack of uniformity within the plantation due to delays in sucker formation, and the market demand for large fruits, are the causes for the small percentage of ratoon 
Figure 4.

A cv. Smooth Cayenne pineapple plant with fruit and several slips.

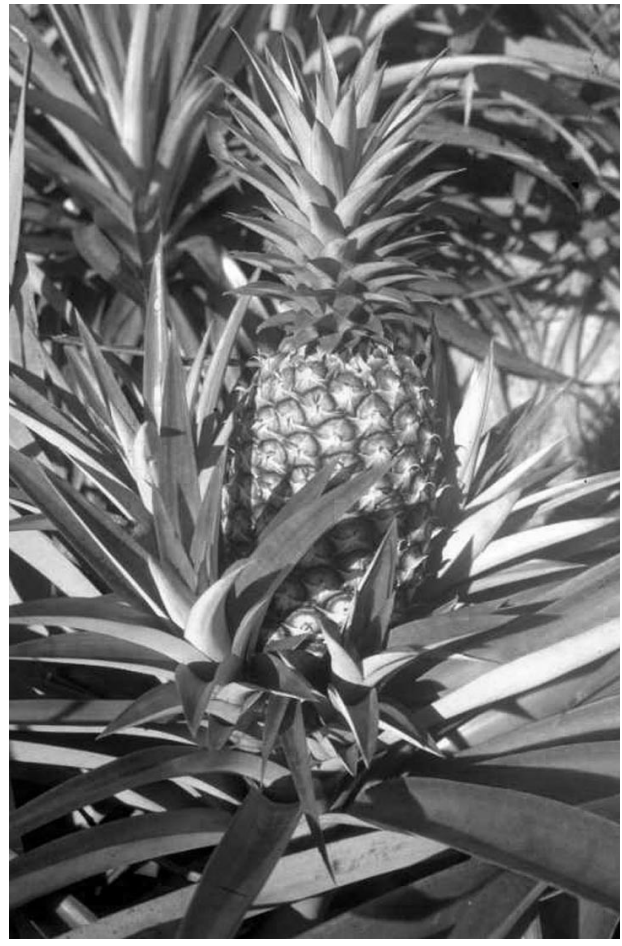

crops in most of the pineapple-producing areas in Brazil, in spite of the much smaller production costs of this crop in comparison with the first cycle crop [4, 11].

Usually the Pérola crops have a smaller production cost per ha than the Smooth Cayenne plantations (table I). This is mainly due to the more expensive planting material and the costs for mealy bugs and wilt control by preventive applications of insecticides in Smooth Cayenne plantations. The differences may be less when the production costs per kg of fruit produced are taken into account. In addition, post-harvest costs may be higher for Pérola fruits. These fruits, having a smaller fiber content and a lower skin and flesh firmness, are more susceptible to transport injuries. Hence, they are usually transported to inland markets on open trucks, together with a few slips per fruit, that serve as its natural packaging [26, 27]. However, due to higher quality requirements by buyers and consumers, an increasing proportion of Brazilian pineapples is now being transported packed in hard paper boxes, a procedure to be generalized in the future in obedience to new standards for fruit classification and packaging to be established by the Brazilian Government in 2001.

All the fruit attributes mentioned above allow classification of Pérola fruits as excellent for the domestic fresh fruit markets, good for the domestic juice industry and still weak for exports, particularly to more demanding markets in Europe or the USA, even though the excellent qualities of that fruit for fresh consumption must still be shown to those consumers (table II). On the other hand, the Smooth Cayenne fruits are excellent for all canneries (juice, slices, etc.), well accepted in foreign markets and less accepted in many domestic fresh fruit markets, especially those in the Northern part of the country [2].

As also shown above and especially in table II, there are several aspects of Pérola pineapple production and commercialization that need further research efforts for improving yield and fruit quality, meeting more and more consumers' requirements. Selection of Pérola clones with fruits of a more cylindrical shape and a more colored (yellow) flesh and skin at the ripe stage could make these fruits more attractive to consumers in Brazil and abroad. This work should first be carried out in some Brazilian pineapple production areas, where there are fields with a Pérola-like variety called Jupi, which frequently has the fruit shape and the flesh color desired. Studies on yellowing of the fruit skin by ethylene treatment are at present being carried out by Embrapa Mandioca e Fruticultura. Preharvest treatments, a common practice for Smooth Cayenne pineapples in many countries, have touched the slips causing them to flower when still attached to the mother plants [27] and hence should be substituted by adequate post-harvest treatments.

Another interesting and ever increasing consumer demand is that for organic products. In Brazil, this new market may be easier to satisfy with Pérola pineapples than Smooth Cayenne ones, given that Pérola plantations often do not require wilt disease and nematode control measures and that Pérola plants are more sensitive to natural flowering and may be more easily forced by natural methods without using 
calcium carbide and other artificial products.

The high susceptibility of both cultivars to Fusarium is one of the major yield-reduction factors of the crop in Brazil and, therefore, has been one of the most relevant research issues. As a result, several integrated - cultural and chemical - control measures have been put into practice and significantly reduced the losses [20]. However, the best and cheapest control measure will be the use of genetically resistant cultivars. The breeding program of Embrapa Mandioca e Fruticultura has selected several resistant genotypes with good general plant and fruit characteristics (Perolera, Primavera, Roxo de Teffé, among others) and has crossed them with Pérola and Smooth Cayenne [28-30]. The program has produced thousands of resistant hybrids and selected the best genotypes along the sexual and three clonal cycles, whose agronomic performances are now being evaluated in different Brazilian ecosystems [31], opening up positive perspectives for getting a definitive solution to this problem in the coming years.

\section{Conclusions}

The overall performance of the Pérola plants and fruits explains the wide use of this variety in Brazil and its potential use in other countries.

Large availability of slips and lower susceptibility to the wilt disease reduce the Pérola production costs, which, in addition to the favorable domestic markets for this fruit, contributes to the preference of a major part of the Brazilian pineapple growers for this variety.

New research efforts and results, including the generation of spineless and Fusarium resistant hybrids, with fruit taste and flavor similar to that of the two traditional cultivars, have opened up good perspectives for further pineapple yield and fruit quality gains, that may also help to meet consumers' requirements in Brazil and abroad.

\section{References}

[1] Leal F., Coppens d'Eeckenbrugge G., Pineapple, in: Janick J., Moore J.N. (Eds.), Fruit breeding. Tree and tropical fruits, Vol. 1, Wiley Publishing Co., New York, USA, 1996, 565-606.

[2] Py C., Lacoeuilhe J.J., Teisson C., The pineapple: cultivation and uses, Maisonneuve et Larose (Eds.), Techniques agricoles et Productions tropicales, Paris, France, 1987, 570 p.

[3] Reinhardt D.H., Souza J. da S., The pineapple industry in Brazil, Acta Hortic. 529 (2000) 57-71.

[4] Reinhardt D.H., Cabral J.R., Souza L.F. da S., Abacaxi. Produção: aspectos técnicos, Embrapa Comun. Transf. Tecnol. (Frutas do Brasil, 7), Embrapa, Brasília, Brazil, 2000, $77 \mathrm{p}$.

[5] Reinhardt D.H., Costa J.T.A., Cunha G.A.P. da, Influência da época de plantio, tamanho de muda e idade da planta para a indução floral no abacaxi Smooth Cayenne no Recôncavo Baiano. 1. Crescimento vegetativo, produção de mudas e florescimento natural, Fruits 41 (1) (1986) 31-41.

[6] Reinhardt D.H., Costa J.T.A., Cunha G.A.P. da. Inflência da época de plantio, tamanho de muda e idade da planta para a indução floral no abacaxi Smooth Cayenne no Recôncavo Baiano. 2. Produtividade e características do fruto, Fruits 42 (1) (1987) 13-23.

[7] Reinhardt D.H., Medina V.M., Crescimento e qualidade do fruto do abacaxi cvs. Pérola e Smooth Cayenne, Pesqui. Agropecu. Bras. 27 (3) (1992) 435-447.

[8] Cabral J.R.S., Matos A.P. de, Cunha G.A.P. da Caracterização morfológico-agronômica de germoplasma de abacaxi, IX Cong. Bras. Frutic., Soc. Bras. Frutic., v.1, Campinas, Brasil, 1987, 35-40.

[9] Cunha G.A.P. da, Cabral J.R.S., Observação sobre a ocorrência de fasciação em abacaxi, Rev. Bras. Frutic. 12 (1) (1990) 19-21.

[10] Carvalho V.D. de, Cunha G.A.P. da, Paula M.B. de, Chitarra M.I.F., Teores de carboidratos no caule de algumas cultivares de abacaxi, Pesquisa Agropecuária Brasileira 20 (2) (1985) 197-200.

[11] Alves A. de A., Reinhardt D.H., Alcântara J. dos P., Souza L.F. da S., Caldas R.C., Manejo e avaliação da soca do abacaxi Pérola nas condições do semi-árido de Itaberaba, Bahia, Rev. Bras. Frutic. 20 (3) (1998) 323-331.

[12] Silva J.R., O adensamento como forma de aumentar a produtividade do abacaxi, Inf. Agropecu. 19 (195) (1998) 62-64. 
[13] Cabral J.R.S., Cultivares de abacaxi, Embrapa Mandioca e Fruticultura, Circ. Téc., 33, Embrapa Mandioca e Fruticultura, Cruz das Almas, Brazil, 1999, 20 p.

[14] Reinhardt D.H., Souza L.F. da, Cunha G.A.P. da, Meneguci J.L.P., Oliveira L. de A. Almeida O.A. de, Souto R.F., Desempenho do abacaxi irrigado, cvs. Pérola e Smooth Cayenne, em diferentes épocas de plantio na região semi-árida do Norte de Minas Gerais, Embrapa Mandioca e Fruticultura, Comun. Téc. 69, 2000, 4 p.

[15] Vieira A., Gadelha R.S. de S., Santos A.C. dos., A aplicação de Fruitone C.P.A. em frutos de abacaxi, Pesqui. Agropecu. Bras. 17 (11) (1982) 1599-1601.

[16] Barbosa N.M.L., Cunha G.A.P. da, Reinhardt D.H., Barros P.G., Controle da floração natural do abacaxizeiro Pérola com uréia e reguladores de crescimento, no Recôncavo Baiano, Rev. Bras. Frutic. 20 (3) (1998) 359-366.

[17] Sanches N.F., Murcha associada à cochonilha Dysmicoccus brevipes (Cockerell, 1893), in: Cunha G.A.P. da, Cabral J.R.S., Souza L.F. da S., (organizadores), O abacaxizeiro - cultivo, agroindústria e economia, Embrapa Comun. Transf. Tecnol., Embrapa, Brasília, Brazil, 1999, pp. 343-366.

[18] Cabral J.R.S., Matos A.P. de, Souto G.F., Reação de germoplasma de abacaxi à inoculações com Fusarium moniliforme var. subglutinans, Pesqui. Agropecu. Brasil. 20 (7) (1985) 787-791.

[19] Matos A.P. de, Souto G.F., Reaction of pineapple, cultivars Pérola and Smooth Cayenne, to inoculation with Fusarium moniliforme Sheld. var. subglutinans WR. \& RG., Fruits 40 (10) (1985) 641-645.

[20] Matos A.P. de, Pineapple fusariosis in Brazil: an overview, Fruits 41 (7/8) (1987) 417-422.

[21] Matos A.P. de, Doenças e seu controle, in: Cunha G.A.P. da, Cabral J.R.S., Souza L.F. da S. (organizadores), O abacaxizeiro - cultivo, agroindústria e economia, Embrapa Comun. Transf. Tecnol., Embrapa, Brasília, Brazil, 1999, pp. 269-305.

[22] Sanches N.F., Pragas e seu controle, in: Cunha G.A.P. da, Cabral J.R.S., Souza L.F. da S. (organizadores), O abacaxizeiro - cultivo, agroindústria e economia, Embrapa
Comun. Transf. Tecnol., Embrapa, Brasília, Brazil, 1999, pp. 307-341.

[23] Sanches N.F., Ataque da broca do talo (Castnia icarus) em abacaxizeiros Pérola e Smooth Cayenne, Rev. Bras. Frutic. 13 (4) (1991) 173-177.

[24] Costa D. da C., Ritzinger C.H.S.P., Nematóides e seu controle, in: Reinhardt D.H., Cabral J.R., Souza L.F. da S. (organizadores), Abacaxi. Produção: aspectos técnicos, Embrapa Comun. Transf. Tecnol., Embrapa, Brasília, Brazil, 2000, pp. 51-55.

[25] Dinardo-Miranda L.L., Spironello A., Martins A.L., Host reaction of pineapple varieties to Pratylenchus brachyurus, Nematol. Bras. 20 (1) (1996) 1-7.

[26] Carvalho V.D. de, Composição, colheita, embalagem e transporte do fruto, in: Cunha G.A.P. da, Cabral J.R.S., Souza L.F. da S. (organizadores), O abacaxizeiro - cultivo, agroindústria e economia, Embrapa Comun. Transf. Tecnol., Embrapa, Brasília, Brazil, 1999, pp. 367-388.

[27] Gonçalves N.B., Abacaxi. Pós-colheita, Embrapa Comun. Transf. Tecnol. (Frutas do Brasil, 5), Embrapa, Brasília, Brazil, 2000, $45 \mathrm{p}$.

[28] Cabral J.R.S., Melhoramento genético. in: Cunha G.A.P.da, Cabral J.R.S., Souza L.F. da S. (organizadores), O abacaxizeiro - cultivo, agroindústria e economia, Embrapa Comun. Transf. Tecnol., Embrapa, Brasília, Brazil, 1999, pp. 83-103.

[29] Cabral J.R.S., Matos A.P. de, Coppens d'Eeckenbrugge G., Segregation for resistance to fusariose, leaf margin type, and leaf color from the Embrapa pineapple hybridization program, Acta Hortic. 425 (1995) 193-200.

[30] Coppens d'Eeckenbrugge G., Cabral J.R.S., Carlier J., Duval M.F., Ferreira F.R., Leal F., Leitão J., Matos A.P. de, Noyer J.L., Suárez Z., The EU-funded project "Evaluation and utilization of pineapple genetic resources from the Amazon to breed resistant varieties", Acta Hortic. 529 (2000) 169-172.

[31] Cabral J.R.S., Reinhardt D.H., Evaluation of pineapple hybrids in different ecosystems of Brazil, Pineapple Newsl. 7 (2000) 10-11. 


\section{Cultivares de piña Pérola y Cayena Lisa en Brasil: crecimiento, floración, plagas y enfermedades, producción y calidad del fruto.}

Resumen - Introducción. Pérola es el cultivar de piña más importante de Brasil, pero es casi desconocido en otros países. Cayena Lisa es el cultivar más sembrado en todo el mundo. Los dos cultivares pertenecen a distintos grupos de piña, y presentan diferentes características botánico-morfológicas, de desarrollo vegetativo y agronómicas. Material y métodos. Se hizo un análisis comparativo entre los dos cultivares, basándose en los resultados y observaciones llevadas a cabo en varios estudios desarrollados en la Embrapa Yuca y Fruticultura, ubicada en Cruz das Almas, Bahia, Brasil, a lo largo de los últimos 20 años. Resultados y discusión. La planta del cv. Pérola normalmente presentó un tallo más pequeño con un menor número de raíces y hojas; sin embargo, las hojas 'D' fueron más largas, más anchas y más erectas. El pedúnculo fue más largo, sosteniendo un fruto más estrecho, más largo, de formato cónico, con la pulpa blanquecina, menos fibrosa, con la médula central comestible, acidez más baja, relación sólidos solubles totales/acidez total titulable y contenido de jugo más elevados. La Pérola fue más sensible a la acción de factores medioambientales y de hormonas inductoras de la floración, pero fue menos susceptible a la enfermedad de la 'Wilt' (desecación de la planta) transmitida por la cochinilha y el excavador del tallo (Castnia icarus). La Pérola produjo mucho más retoños del tipo bulbillo, a pesar de la formación de brotes del tallo ser más tardía y menos uniforme; además, están menos arrestados a la planta-madre, volviéndose, de esta forma, más difícil la obtención de un buen rendimiento de la segunda cosecha. Conclusión. El potencial de rendimiento de la Pérola fue más bajo debido al menor peso del fruto y a la menor densidad de cultivo empleada. Su coste de producción también fue más bajo, principalmente debido al material de siembra más barato y menor número de aplicaciones de pesticidas. El comportamiento general de las plantas y frutos del cv. Pérola señalan la gran utilización de esta variedad en Brasil y su potencial uso en otros países.

Brasil / Ananas comosus / ensayos de variedades

To access this journal online: www.edpsciences.org 
